\title{
Transgender Dalam Persepsi Masyarakat
}

\author{
Nurdelia \\ Jasruddin \\ Universitas Negeri Makassar \\ jasruddin@unm.ac.id \\ Jasmin Daud \\ Universitas Negeri Makassar \\ jasmindaud@unm.ac.id
}

\begin{abstract}
ABSTRAK
Fenomena transgender dalam masyarakat mendapatkan berbagai macam reaksi. Kasus-kasus pun banyak bermunculan sehingga membutuhkan penanganan. Dalam penelitian ini memfokuskan pada persepsi masyarakat kota Makassar terhadap keberadaan transgender. Untuk menjawabnya peneliti menggunakan pendekatan secara agama dan sosiologi. Adapun jenis penelitian ini adalah kuantitatif deskriptif dengan menggunakan metode survey, yaitu dengan melakukan pendekatan langsung terhadap masyarakat kota Makassar sebagai sasaran melalui penyebaran angket/questioner kepada masyarakat. Berdasarkan hasil penelitian, dipaparkan mengenai persepsi yang diberikan masyarakat Makassar tentang keberadaan transgender.Peneliti menemukan jawaban yang bervariasi dari responden mengenai persepsi tentang transgender secara subjektif.Dapat diketahui bahwa transgender adalah orang yang memiliki kelainan biologis misalnya terlahir dengan dua alat kelamin dan adapula yang disebabkan oleh beberapa faktor eksternal seperti adanya pengaruh lingkungan pergaulan.
\end{abstract}

Kata Kunci: Persepsi, Masyarakat, Transgender

\section{PENDAHULUAN}

Lingkungan memberi pengaruh pada perkembangan pribadi individu melalui penanaman nilai-nilai, norma-norma, maupun aturan-aturan yang dianut dalam suatu masyarakat. Masing-masing masyarakat memiliki nilai-nialai, norma-norma maupun aturan yang berbeda dengan kelompok masyarakat lainnya.Nilai-nilai yang berlaku dalam masyarakat dijadikan panutan dan merupakan perwujudan dari nilai-nilai budaya dan agama masyarakat setempat. Salah satu tuntutan dari lingkunganya adalah manusia harus mampu menyesuaikan diri dengan individu lain sesuai dengan norma, aturan, nilai-nilai yang berlaku di masyarakat, baik di dalam maupun diluar kelompok.

Masyarakat Sulawesi selatan, khususnya Makassar yang menganut sistem patriarkhi memberikan proses sosialisasi yang berbeda terhadap pengenalan nilai-nilai hidup. Sosialisasi konstruksi sosial secara evolusional dan perlahan-lahan mempengaruhi biologis masing-masing jenis kelamin.Konstruksi sosial yang membedakan peran, kedudukan, perilaku, dan pembedaan relasi sosial antara laki-laki dan perempuan yang 
pada akhirnya didefinisikan sebagai gender. Salah satu contoh sosialisasi gender adalah, kaum laki-laki harus bersifat kuat dan agresif, akibatnya laki-laki kemudian terlatih dan tersosialisasikan untuk menjadi atau mengarah kepada sifat gender maskulin, dimana secara fisik lebih kuat dan lebih besar. Sebaliknya kaum perempuan haruslah lemah lembut, irrasional, emosional, cantik, akibatnya kemudian perempuan diarahkan menuju ke sifat gender feminine. Proses sosialisasi gender tidak saja berpengaruh pada perkembangan emosi dan visi serta ideologi kaum laki-laki dan perempuan, tetapi juga mempengaruhi perkembangan fisik dan biologis yang dialami. Dengan adanya sosialisasi gender, perlakuan terhadap anak laki-laki secara fisik lebih keras dibanding perlakuan terhadap anak perempuan sehingga laki-laki secara fisik dibentuk lebih kuat dibanding anak perempuan. Secara psikologis, proses sosialisasi ini menyebabkan munculnya perbedaan perilaku komunikasi antara anak laki-laki dan anak perempuan.

Anak laki-laki dalam latar budaya Makassar diarahkan menjadi laki-laki yang harus memiliki sifat berani, sebagai akibatnya, banyak diantara mereka yang menjadi salah kaprah didalam menerapkannya, salah arah dalam berkomunikasi, dan bahkan cenderung kearah agresif, yakni ingin menang sendiri, tidak mau menerima pendapat orang lain karena merasa yakin benar pada pendapatnya sendiri walaupun untuk orang lain hal itu belum tentu benar. Sebaliknya pada anak perempuan dengan sifat-sifat yang harus lemah lembut, tidak sedikit diantara mereka yang mengalami kesulitan dalam berkomunikasi akibat sifat peran gender yang ditimpakan.

Salah satu bentuk perilaku yang diangap menyimpang dari peran gender yang telah dikonstruksikan ini adalah transgender, yaitu orang-orang yang mengidentifikasikan seksualnya secara gender berbeda dari jenis kelaminnya secara biologis (Linda, 2011:15).Kehadiran seorang waria merupakan suatu proses yang panjang, baik secara individual maupun sosial. Secara individual antara lain, lahirnya perilaku waria tidak lepas dari suatu proses atau dorongan yang kuat dari dalam dirinya, bahwa fisik mereka tidak sesuai dengan kondisi psikis, hal ini menimbulkan konflik psikologis dalam dirinya. Mereka mempresentasikan perilaku yang jauh berbeda dengan laki-laki, tetapi bukan sebagai perempuan. Permasalahannya tidak sekedar menyangkut masalah moral dan perilaku yang dianggap tidak wajar, namun merupakan dorongan seksual yang sudah menetap dan memerlukan penyaluran. Berbagai dorongan seksual waria belum sepenuhnya dapat diterima oleh masyarakat, secara normatif tidak ada kelamin ketiga di antara laki-laki dan perempuan.Dalam penelitian ini, penulis ingin menjelaskan terkait “Transgender Dalam Persepsi Masyarakat Kota Makassar .Hal tersebut untuk memahami 
bagaimana persepsi masyarakat terhadap keberadaan transgender sebagai kelompok minoritas yang termarjinalkan.

\section{LANDASAN TEORI}

Secara etimologi transgender berasal dari dua kata yaitu "trans" yang berarti pindah (tangan; tanggungan; perubahan); pemindahan dan "gender" yang berarti jenis kelamin (Pius dan Dahlan dalam Nur Fadilatul, 2013: 16). Selanjutnya menurut Peletz (2006) mengartikan kata trans sebagai pergerakan melintasi ruang dan batas, sama dengan merubah hal yang bersifat alamiah, natural. Pengertian 'trans' bermakna menggabungkan suatu entitas atau proses atau hubungan antara dua fenomena.

Transgender ialah orang yang cara berperilaku atau penampilannya tidak sesuai dengan peran gender pada umumnya. Transgender adalah orang yang dalam berbagai level "melanggar" norma kultural mengenai bagaimana seharusnya laki-laki dan perempuan itu. Seorang perempuan misalnya, secara kultural dituntut untuk bersikap lemah lembut.Tetapi jika seorang laki-laki yang berkarakter demikian, itu namanya transgender (Linda Sudiono dalam Outline Sekolah Feminis Untuk Kaum Muda Perempuan Mahardika 2011: 17).Selanjutnya istilah trangender diartikan oleh Fausiah (2011 dalam Nur Sakina) sebagai suatu terminologi yang disematkan kepada keaneka ragaman indidu, perilaku, kelompok-kelompok yang dianggap memiliki kecendrungan yang dianggap menyimpang dari peran gender yang dianggap normatif (laki-laki atau perempuan) secara umum, namun tidak selalu ditetapkan pada saat kelahiranya, dan juga peraan yang secara tradisional ditetapkan oleh masyarakat. Transgender merupakan pernyataan identitas gender seseorang. Transgender tidak menyatakan secara langsung berbagai bentuk spesifik dari orientasi seksual.Ia merupakan suatu terminologi payung yang sering digunakan untuk menjelaskan suatu tingkatan yang luas mengenai identitas dan pengalaman.

Transgender merupakan suatu bentuk prilaku baik oleh individu maupun kelompok yang menggunakan atribut gender diluar dari yang dikonsturksikan oleh masyarakat, yang dianggap menyimpang dari perang gender (laki-laki atau perempuan), nilai, norma serta agama secara umum.Namun tidak selalu ditetapkan pada saat kelahiran.Perlu digaris bawahi bahwa transgender dan transeksual adalah permasalahan yang berbeda, yang membedakan keduanya adalah transgender belum pasti merupakan transeksual, karena orang yang mengubah sifat dan perilakunya berbanding terbalik dengan kodratnya belum tentu mengubah jenis kelaminnya. Misalnya: laki-laki yang 
tidak tegas dalam bertindak dan berperilaku, mereka terkesan melambai, berbicara seperti perempuan, dan menyukai hal-hal yang disukai oleh perempuan pada umumnya. Begitupun sebaliknya dengan yang terjadi pada perempuan yang memiliki perilaku menyimpang dari kodratnya, mengubah semua penampilan dan perilakunya seperti lakilaki.Sedangkan transeksual sudah pasti dapat dikatakan transgender. Karena transeksual merupakan perilaku mengubah dirinya secara total termasuk jenis kelamin yang dimiliki, karena faktor ketidaknyamanan akhirnya memutuskan untuk berganti jenis kelamin dan mengubah perilakunya secara menyeluruh (Dian Puspitasari: 2012 ).

Identitas merupakan salah satu tema sentral di hadapan globalisasi.Sentralnya tema ini bisa dipahami karena globalisasi membawa efek historis baru yang tidak bisa dipungkiri, yakni sebuah masyarakat global atau lebih khusus lagi sebuah masyarakat multikultural yang kemudian memberi rasa keberakaran dan juga rasa memiliki.Dalam hal ini, identitas selalu melekat pada masing-masing individu maupun komunitas serta menjadi unsur pokok dalam interaksi sosial.

Terbentuknya identitas gender dapat dijelaskan berdasarkan tiga teori psikologi yaitu teori psikoanalisis, teori sosialisasi dan teori perkembangan kognitif. Teori psikoanalisis pertama kali diperkenalkan oleh Sigmund Freud (1856-1939). Teori ini menjelaskan secara konseptual bagaimana identitas gender terjadi pada seorang individu (Nasaruddin2001:45). Teori psikoanalisis atau teori Freud, sesuai dengan nama pencetusnya, Sigmund Freud, menjelaskan perilaku seseorang dengan mengaitkanya pada faktor biologis itu misalnya evolusi, gen, dan anatomi.

Teori belajar social (social-learning theory) menjelaskan berdasarkan konsep nature-nurture dan melihat bahwa perbedaan peran gender merupakan hasil dari tuntutan dan harapan lingkungan. Identitas gender merupakan hasil struktur masyarakat yang patriarchal (Saparinah dan Soematri 1995: 73). Teori perkembangan kognitif adalah teori interaksi yang menekankan pada interaksi antara keadaan organism, terkait perkembangan kognitifnya, dan informasi yang ada dalam lingkungan budaya.Perilaku yang khas bagi salah satu gender-gender specific behavior atau traits-adalah interaksi antara pengetahuan kognitif didalam diri seseorang dan informasi yang ada dalam lingkungan budaya.Sumbangan dari teori belajar sosial adalah penekanannya pada komponen sosial dan budaya dari perkembangan prilaku yang sesuai gender (gender specific behavior). Teori ini menjelaskan bagaimana anak perempuan dan anak laki-laki sejak lahir diasuh/diperlakukan berbeda. Dengan menerapkan konsep penguatan dan konsep meniru, anak secarah terarah memilih dan mengisi peran gendernya.penguatan 
terjadi bila orang tua atau orang lain memberikan hadiah dengan warna tertentu, jenis mainan tertentu, atau dengan cara memberikan hadiah bila memperlihatkan perilaku yang diinginkan. Penguatan juga terjadi melalui penggunaan kata yang khas karena ia anak perempuan atau anak laki-laki (Saprina, Sadli 2010: 29 )

Identitas sosial kaum waria diperoleh dari keterlibatannya dalam suatu kelompok budaya. Untuk memperoleh identitas sosial biasanya melalui proses pencarian dan pendidikan dalam jangka waktu tertentu. Dasar pembentukan identitas sosial antara lain: ras, etnis, seksualitas, kelas, dan gender. Sedangkan identitas budaya diperoleh kaum waria karena mereka menjadi bagian dari kebudayaan tertentu.Identitas budaya ini dapat meliputi pembelajaran dan penerimaan terhadap tradisi, sifat bawaan, bahasa, agama, dan keturunan dalam suatu kebudayaan.Proses menjadi cantik, mengungkapkan tuturan dengan suara wanita yang lemah lembut, gerak gerik yang lemah nan gemulai, dan karakter keibu-ibuan merupakan cara kaum waria untuk mengaktualisasikan kelompoknya di tengah masyarakat. Hal tersebut menjadi bentuk usaha mendapatkan jati diri yang sesuai dengan kehidupan psikologis kaum waria yang menyimpang dari kehidupan biologisnya.Usaha yang dilakukan oleh para waria merupakan bukti bahwa ciri-ciri biologis harus diubah untuk menciptakan satu konstruksi sosial agar mereka dipahami secara sosial sebagai wanita.

Puspitosari (2005 ) mengatakan bahwa faktor-faktor terjadinya transgender adalah karena disebabkan oleh faktor biologis yang dipengaruhi oleh hormon seksual dan genetik seseorang. Selain itu, transgender juga disebabkan oleh faktor psikologis, sosial budaya yang termasuk didalamnya pola asuh lingkungan yang membesarkannya.Dalam kasus ini, pelaku biasanya mempunyai pengalaman yang sangat hebat dengan lawan jenis sehingga mereka berkhayal dan memuja lawan jenis sebagai idola dan ingin menjadi seperti lawan jenis (Muthi'ah, 2007: 40).

Verderber (dalam Mugniesyah 2000) mengemukakan bahwa persepsi merupakan proses memberikan makna terhadap informasi yang diperoleh indera kita, atau dapat dikatakan sebagai apa yang dikerjakan otak dengan informasi yang diperolehnya. Menurut Rahmat (dalam Al-fiani, 2006: 34) persepsi ialah proses pengamatan individu yang berasal dari komponen-komponen kognisi yang dipengaruhi oleh faktor-faktor pengalaman, proses belajar. Prinsip yang mendukung terjadinya suatu persepsi sangat penting karena makin baik suatu obyek, orang, peristiwa atau hubungan diketahui, makin baik obyek, orang, peristiwa atau hubungan tersebut dapat di ingat.Persepsi merupakan suatu penafsiran terhadap situasi, dan bukan suatu pencatatan dyang benar terhadap 
situasi.Persepsi seorang atau kelompok dapat jauh berbeda dengan persepsi orang atau kelompok lain sekalipun dalam situasi yang sama. Perbedaan persepsi ini dapat ditelusuri dengan adanya perbedaan individual, perbedaan kepribadian, perbedaan sikap atau perbedaan dalam motivasi.

\section{METODE PENELITIAN}

Jenis penelitian ini adalah kuantitatif deskriptif, yaitu jenis penelitian yang menjelaskan atau menggambarkan suatu fenomena, dalam hal ini persepsi masyarakat Kota Makassar terhadap keberadaan transgender.fokus penelitian adalah transgender dalam persepsi masyarakat.Sumber data terdiri dari data primer dan data sekunder.Instrumen penelitian adalah peneliti sendiri sebagai instrumen utama dan alat seperti kamera, alat perekam dan lembar observasi.Informan ditentukan secara purposive sampling, teknik pengumpulan data yaitu observasi, wawancara dan dokumntasi, Analisa data yang digunakan pada penelitian ini statistik deskriptif dengan menggunakan pengelompokan, penyederhanaan, serta penyajian data dan menggunakan teknik keabsahan data triangulasi.

\section{PEMBAHASAN}

Persepsi masyarakat terhadap keberadaantransgender pada pernyataan empat "transgender bertentangan dengan norma-norma sosial yang ada didalam masyarakat!". Menunjukkan bahwa 46\% masyarakat sangat setuju, 35\% setuju, 15\% tidak setuju dan 4\% sangat tidak setuju". Sehingga dapat ditarik kesimpulan bahwa pada umumnya masyarakat Makassar masih menggap perilaku transgender sebagai suatu perilaku yang menyimpang dari nilai-nilai norma sosial yang dianut oleh masyarakat Kota Makassar .Selanjutnya pada pernyataan delapan "masyarakat berharap adanya peraturan mengenai transgender!".23\% masyarakat sangat setuju, $67 \%$ setuju, dan $10 \%$ tidak setuju.Menunjukan bahwa umumnya masyarakat setuju tentang adanya peraturanperaturan terkait kebijakan yang diberikan oleh pihak pemerintah kepada kelompok transgender. Hal ini dipengaruhi oleh pola pikir masyarakat kota yang umumnya semakin maju dan mulai membuka diri pada perubahan-perubahan disekitarnya.Pada pernyataan sepuluh "Kelompok transgender memiliki hak untuk berkeluarga dengan sesamanya!". $3 \%$ masyarakat sangat setuju, 6\% yang setuju, 19\% tidak setuju dan 72\% masyarakat sangat tidak setuju. Dominan masyarakat berada pada pilihan sangat tidak setuju dimana perilaku perkawinan sejenis merupakan suatu perilaku yang menyimpang dari norma 
agama dan norma sosial didalam masyarakat sehingga perilaku ini masih dianggap sebagai suatu perikau yang dianggap tabu didalam masyarakat Makassar sebagaimana anggapan masyarakat beragama sebagai wujud dari pemaknaan agama bahwa perilaku kelompok transgender merupakan dosa besar karena sejatinya kelompok ini telah merubah apa yang telah digariskan Tuhan yang maha ketika kemudian orang-orang keluar dari batas yang digariskan tuhan maka dengan sendirinya mereka akan mendapat stigma negatif dari masyarakat sebagai pendosa termasuk halnya transgender yang melakukan pernikahan sejenis.Selanjutnya pada pernyataan tigabelas "kelompok transgender memiliki hak untuk aktif dalam kegiatan politik $4 \%$ masyarakat sangat setuju, 19\% setuju, 49\% tidak setuju dan 28\% sangat tidak setuju. Menunjukkan bahwa umumnya masyarakat Kota Makassar tidak setuju untuk melibatkan kelompok transgender dalam kegiatan politik hal ini dikarenakan oleh perilaku dan orientasi seksual yang dianggap tidak sesuai dengan agama dan norma sosial sehingga masyarakat merasa kelompok transgender tidak seharusnya terlibat dalam gerakan politik apalagi jika itu berkenaan dengan kepemimpinan. Karenanya kiprah transgender dalam dunia politik hanya sebagai icon yang digunakan oleh lembaga tertentu untuk memenuhi kebutuhan lembaga tersebut seperti penyuaran pengunaan alat kontrasepsi untuk mencegah terjadi penularan HIV/AIDS dimana pada pelaksanaannya transgender menjadi salah satu iconnya.Pada pernyataan tujuhbelas "masyarakat berharap adanya sikap saling menghargai antar masyarakat dengan kelompok transgender!”. Dengan persentase sebesar $18 \%$ masyaraakat sangat setuju, $73 \%$ setuju, $7 \%$ tidak setuju dan $2 \%$ sangat tidak setuju. Menunjukan bahwa dominan masyarakat setuju dengan adanya sikap saling menghargai antara masyarakat dengan kelompok transgender karena dengan adanya sikap tersebut masyarakat dan kelompok transgender dapat hidup berdampingan secara damai tanpa ada diskriminasi terhadap kelompok lainnya.Terakhir, berdasarkan tabel 4.21 menunjukkan bahwa jumlah rata-rata tanggapan responden terhadap seluruh pernyataan, memperlihatkan bahwa jumlah responden yang menyatakan sangat setuju (14,12\%), responden yang menyatakan setuju (46,29\%), responden yang menyaatakan tidak setuju $(27,65)$, dan responden yang menyatakan sanga tidaksetuju $(12,69 \%)$.Keberadaan kaum Transgender di Kota Makassar dapat bertahan hingga sekarang ini lebih dikarenakan bahwa pada beberapa sisi tertentu, masyarakat bisa menerimanya dengan mudah. Penerimaan itu terjadi salah satunya dikarenakan beberapa anggota masyarakat menganggap kaum transgender di Kota Makassar dapat memberi keuntungan sosial, ekonomi dan politik pada mereka. Meski terkesan memanfaatkan, hanya saja kondisi ini 
juga dapat memberi keuntungan pada kelompok transgender untuk tetap membangun hubungan sosial dengan anggota masyarakat yang melakukan proses sosial tersebut.

\section{KESIMPULAN}

Dalam kacamata normatifitas agama dan etika masyarakat konvensional, keberadaan kaum transgender menjadi sesuatu hal yang tertolak dengan sendirinya. Hal ini dikarenakan aturan umum yang berlaku senantiasa tidak menyediakan tempat bagi hidupnya aktifitas-aktifitas yang dianggap negatif dan tidak sesuai dengan koridor kesusilaan, apalagi bagi kelompok sosial yang telah menerima citra dan stigma (label) yang dekat dengan nuansa seperti pelacuran dan perbuatan maksiat lainnya.Oleh karena itu, Jika hal tersebut diposisikan berhadap-hadapan dengan keberadaan kaum waria di Kota Makassar ,maka akan terjadi sebuah perbenturan kebudayaan. Akan tetapi, hal ini tidak kemudian lantas menutup peluang untuk melakukan negosiasi sosial diantara keduanya, sebab pada beberapa sisi tertentu, dua kebudayaan yang saling berbeda dapat dipertemukan dan menjalin harmonisasi kebudayaan. Asumsi dasarnya lahir karena padatiap kebudayaan tertentu memiliki unsur yang niscaya saling terkait satu sama lain, sehingga peluang untuk diterimanya (kompromi) kebudayaan yang tadinya saling bertolak menjadi dimungkinkan dan menciptakan harmonisasi budaya dalam sebuah masyarakat.

Demikian pula halnya jika dikontekskan dengan topik serta hasil penelitian dalam tulisan ini,keberadaan kaum Transgender di Kota Makassar dapat bertahan hingga sekarang ini lebih dikarenakan bahwa pada beberapa sisi tertentu, masyarakat bisa menerimanya dengan mudah. Penerimaan itu terjadi salah satunya dikarenakan beberapa anggota masyarakat menganggap kaum waria di Kota Makassar dapat memberi keuntungan sosial, ekonomi dan politik pada mereka. Meski terkesan memanfaatkan. hanya saja kondisi ini juga dapat memberi keuntungan pada waria untuk te membangun hubungan sosial dengan anggota masyarakat yang melakukan proses sosial tersebut.

\section{DAFTAR PUSTAKA}

Arbani.(2012). Kejahatan Kebancian (Hate Crime) Terhadap Transgender (MaleTo Female) dan Waria.Depok: Universitas Indonesia 
Ayuningtyas, Paramita. (2009). Identitas Diri Yang Dinamis:Analisis Identitas Gender Dalam Novel Breakfast On Pluto Karya Patrick Mccabe. Depok: Universitas Indonesia

Azwar, Saifuddin. (1997). Sikap Manusia Teori dan Pengukurannya (edisi ke 2). Yogyakarta: Pustaka Pelajar.

B, A'malia. (2010). Fashion Dan Identitas Diri Waria (Studi Etnografi Simbol simbol Komunikasi Non-verbal dalam Fashion Sebagai Pembentuk Identitas Diri di kalangan Waria di kota Yogyakarta). Yogyakarta: Universitas Sebelas Maret

Dahlan, Al-fiani.(2006). Kecendrungan BerprilakuTawuran Ditinjau Dari Kontrol Diri Dan Persepsi Terhadap Tersedianya Dukungan Dari Teman Sebaya Pada Remaja Di Kota Makassar. Makassar: Universitas Negeri Maakassr.

Fadilatul, Nur. (2013). Fenomena Transgender Dalam Hadis Nabi SAW( Pemaknaan Hadis Dalam Sunan Abu Dawud Nomor Indeks 4930). Surabaya: Institut Agama Islam Negeri sunan Ampel.

Jannah, Roudlotul. (2013). Pola Interaksi Sosial Masyarakat Dengan Waria Di Pondok Pesantren Khusus Al-Fatah Senin Kami. Semarang: Universitas Negeri Semarang.

Kartono, Kartini. (2007). Patologi Sosial.Jakarta: Rajawali Pers.

LGBT Nasional Indonesia.(2013). Hidup sebgai Lgbt di Asia.Jakarta: USAID Indonesia.

Masalah Sosial budaya.Warta Warga.(2010) 2010/04/masalah-sosial-budaya-13. WIT.

Transgender dan Transeksual.1 Oktober (2012).http://www.dian-puspita fib11.web.unair.ac.id.transgender-dan-transeksual.htm.Disunting pada $8 \mathrm{Mei}$ 2015 pukul 14:20 WIT.

Mugniesyah.(2000). Persepsi Peran Gender. Bogor: Institut Pertanian Bogor

Putri, Dwi. (2012). Aspek Kejiwaan Kelompok transgenderdan Transeksual. Kuningan Jawabarat. Sekolah Tinggi Ilmu Kesehatan Kuningan

Ramadhani, Abd. Azis.(2012). Homoseksual Dalam Perspektif Hukum pidana dan Hukum Islam. Suatu Studi Komparatif Normatif. Makassar: Universitas Hasanuddin.

Sadli, Saprina. (2010). Berbeda Tapi setara: Pemikiran Tentang Kajian Perempuan. Jakarta: Kompas.

Sakina, Nur. (2011). Pola Penangganan Konflik Lembaga Swadaya Masyarakat 
Arus Pelangi Dengan Front Pembela Islam Dan Hizbut Tahrir Indonesia. Jakarta: Universitas Islam Negeri Syarif Hidayatullah Jakatra

Sayful.(2011). Strategi Kaum Waria Mempertahankan Eksistensinya di Makassar, Sulawesi Selatan. Makassar: Universitas Hasanuddin

Soekanto, Soerjono. (1988). Sosiologi Penyimpangan. Jakarta: Rajawali Pers

Soekanto Soerjono.(2007). Sosiologi Suatu Pengantar. Jakarta: PT Raja Grafindo Persada

Suyanto, Bagong dan Narwoko J. Dwi. (2007). Sosiologi Pengantar dan Terapan (edisi kedua). Jakarta: Kencana.

Umar, Nasaruddin. (2001). Argumentasi Kesetaraan Gender Perspektif al-Quran. Jakarta: Paramadina. 